\title{
Applied Entomology and Zoology Vol. 56, No. 1 目次
}

(2021 年 2 月 25 日発行)

\section{ORIGINAL RESEARCH PAPERS}

Seasonal adult occurrence of a coccidophagous ladybird, Telsimia nigra (Coleoptera: Coccinellidae), in citrus groves in central Japan [日本のカンキツ園におけるカイガラムシ食テ ントゥムシ，クロテントウ（コウチュウ目：テントウムシ科）成 虫の季節消長]

Shuji Kaneko (金子修治) 1

A comparison of the mechanisms controlling the hatching time and synchrony of the desert locust Schistocerca gregaria and the Bombay locust Nomadacris succincta (Orthoptera: Acrididae) [サバクトビバッタとタイワンッチイ ナゴ (バッタ目：バッタ科) の一斉ふ化を制御する仕組みの比較］ Seiji Tanaka (田中誠二) 9

Sex pheromone of the fall armyworm Spodoptera frugiperda (Lepidoptera: Noctuidae) of a "Far East" population from Okinawa, Japan [ツマジロクサヨトゥ (チョウ目:ヤガ科) 沖縄個体群の性フェロモン]

Sadao Wakamura · Norio Arakaki - Shin-ichi Yoshimatsu (若 村定男·新垣則雄 $\cdot$ 吉松慎一) 19

Survey of mermithid nematodes (Mermithida: Mermithidae) infecting fruit-piercing stink bugs (Hemiptera: Pentatomidae) in Japan [日本の果樹カメムシ類 (カメムシ目：カメムシ科)に寄生するシヘンチュウ (シヘンチュ ウ目 : シヘンチュウ科) の調查]

Shu Watanabe A Ayaka Tsunashima Kyo Itoyama Ryoji Shinya（渡部 就・綱島彩香・糸山 享·新屋良治） 27

Development and characterization of novel microsatellite markers for a dominant parasitoid Stethynium empoasca (Hymenoptera: Mymaridae) in tea plantations using highthroughput sequencing [ハイスループットシーケンシングを用 いたチャ園の主要な寄生蜂 Stethynium empoasca (ハチ目：ホソハ ネコバチ科) の新規マイクロサテライトマーカーの開発と解析］

Jinyu Li $\cdot$ Longqing Shi $\cdot$ Jie Chen $\cdot$ Minsheng You $\cdot$ Shijun You 41

The hatching-stimulation activity of solanoeclepin A toward the eggs of Globodera (Tylenchida: Heteroderidae) species [グロボデラ属（ティレンクス目：へテロデラ科）のセン チュウの卵に対するソラノエクレピン A のふ化促進効果]
Itaru Sakata A Atsuhiko Kushida - Keiji Tanino (坂田 至 - 吕 田篤彦・谷野圭持） 51

Suppression effect of intercropping with barley on Thrips tabaci (Thysanoptera: Thripidae) in onion fields [タマネギ 圃場へのオオムギ間作導入によるネギアザミウマ (アザミウマ目: アザミウマ科) の密度抑制]

Takayuki Sekine $\cdot$ Toshio Masuda $\cdot$ Shota Inawashiro (関根崇 行 ·増田俊雄 $\cdot$ 猪苗代翔太） 59

Effect of soil moisture on pupation behavior and inhabitation of Spodoptera frugiperda (Lepidoptera: Noctuidae) [土 壌水分がッマジロクサヨトウ (チョウ目：ヤガ科) の蛹化行動と 生息に打ける土壌水分効果]

Yan Shi $\cdot$ Lin-Yu Li $\cdot$ Sohaib Shahid $\cdot$ Guy Smagghe $\cdot$ TongXian Liu 69

Distribution of Rotylenchulus reniformis (Tylenchida, Hoplolaimidae) reproductive types in Kyushu, Japan [ニセ フクロセンチュウ (ティレンクス目：ホプロライムス科) 生殖型 の九州での分布]

Kazuki Nakae · Toyoshi Yoshiga（中江和紀・吉賀豊司） 75

Evaluation of seven green manure crops as antagonists against larvae of Scepticus griseus (Coleoptera: Curculionidae), an insect pest of vegetables and field crops [トビイロヒョウタンゾウムシ (コウチュウ目：ゾウムシ科)の幼 虫に対する対抗植物としての 7 種緑肥作物の評価]

Hiroshi Oida - Hiroshi Fukuda - Kenji Suzuki (大井田 寞・福 田 寛・鈴木健司） 83

Chromosome mapping of attP landing sites in the strains for phiC31 integrase-mediated transgenesis of Drosophila prolongata (Diptera: Drosophilidae) [テナガショウジョウバエ (ハエ目：ショウジョウバエ科)に打ける phiC31 インテグレース の利用に向けた $a t t P$ 配列挿入部位の推定 $]$

Ayumi Kudo (工藤愛弓) 91

Photoperiodic induction of reproductive diapause and lifehistory traits of a tortoise beetle, Laccoptera nepalensis (Coleoptera: Chrysomelidae), a range-expanding pest of southern origin [分布を拡大中の南方性害虫のヨッモンカメ) コハムシ (コウチュウ目：ハムシ科)に打ける光周期による生殖 
休眠の誘導と生活史形質]

Yoshinori Shintani · Yuya Takahashi $\cdot$ Kenji Nakagawa $\cdot$ Yuki Mineshima (新谷喜紀・高橋佑弥・中川健史・峰嶋佑樹) 99

Role of host vibration and cuticular hydrocarbons in host location and recognition by Haplogonatopus oratorius (Hymenoptera: Dryinidae) [寄主の振動と体表炭化水素がクロ 八ラカマバチ (ハチ目：カマバチ科) の寄主探索や寄主認識に果 たす役割]

Tetsuya Hirota ・ Toshiharu Mita（廣田哲也・三田敏治）

107

Toxicity and sublethal effects of chlorantraniliprole and indoxacarb on Spodoptera littoralis (Lepidoptera: Noctuidae) [クロラントラニリプロールとインドキサカルブのエジプトヨト ウ (チョウ目：ヤガ科)に対する毒性と亜致死効果]

Moataz A. M. Moustafa - Eman A. Fouad - Yasmin AbdelMobdy $\cdot$ Kamirán Áron Hamow $\cdot$ Zsanett Mikó $\cdot$ Béla Péter Molnár · Adrien Fónagy

\section{TECHNICAL NOTES}

Characterization of microsatellite loci for three species of Tomoplagia (Diptera: Tephritidae) and absence of crossspecies amplification [Tomoplagia (ハエ目 : ミバエ科) 3 種のマ イクロサテライト遺伝子座の解析と種間クロス増幅の不発生] Camila R. O. Leal • Leonardo Ré Jorge • Anete P. de Souza • Thomas M. Lewinsohn • Karina L. Silva-Brandão

125

Development of a multiplex PCR system to discriminate the alleles of the brown planthopper resistance locus $B P H 1$ in rice (Oryza sativa L.) [イネ (Oryza sativa L.) のトビイロウ ンカ抵抗性 $B P H 1$ 座のアリルの種類を判別するマルチプレックス PCR 法の開発]

Mikio Ikoma - Yoshinori Hatakeyama - Yasumori Tamura (生 駒樹央·畠山吉則 $\cdot$ 田村泰盛) 133 